\title{
PANCASILA DALAM POLITIK PENCITRAAN DI INDONESIA
}

\section{Lutfi Fahrul Rizal}

UIN Sunan Gunung Djati Bandung, Indonesia

Correspondence: lutfifahrulrizal@uinsgd.ac.id

Received: 03 Mei 2021; Accepted: 27 September 2021; Published: 30 September 2021

\begin{abstract}
This study aims to measure the level of appreciation and practice of the values of Pancasila as the ideology of the Indonesian nation as a whole, so that the values in it can really be applied in the life of the nation and state. This research uses a normative-empirical method, namely by combining legal research methods that not only view law as a prescriptive and applied discipline, but also have a descriptive nature based on the reality of the development of law itself in society. There are several phenomenal events that are closely related to Pancasila, where these events illustrate that noble values that are actually respected and upheld are still vulnerable to being exploited by their sensitivity by some groups for imaging purposes without paying attention to the noble values of Pancasila. Pancasila is vulnerable to being used as a political commodity, so that certain groups feel that it is Pancasilaist and other groups are not Pancasilaist. The results of this study provide an indication that all groups should be able to place Pancasila as an ideology in the nation and state, and become a joint evaluation in revitalizing the noble values contained in Pancasila as the basic rules, guidelines and philosophy of life of the Indonesian nation that must be practiced as the embodiment of Bhineka Tunggal Ika.
\end{abstract}

Keywords: Pancasila; politics; image.

\begin{abstract}
Abstrak
Penelitian ini bertujuan untuk mengukur tingkat penghayatan dan pengamalan nilainilai Pancasila sebagai ideologi bangsa Indonesia secara utuh, sehingga nilai-nilai di dalamnya benar-benar dapat diterapkan dalam kehidupan berbangsa dan bernegara. Penelitian ini menggunakan metode normatif-empiris, yaitu dengan cara melakukan penggabungan metode penelitian hukum yang tidak hanya memandang hukum sebagai disiplin yang bersifat preskriftif dan terapan, namun sekaligus bersifat deskriptif yang didasarkan pada kenyataan perkembangan hukum itu sendiri di masyarakat. Ada beberapa peristiwa fenomenal yang erat hubungannya dengan Pancasila, di mana peristiwa ini memberi gambaran bahwa nilai-nilai luhur yang sejatinya dihormati dan dijunjung tinggi masih rentan dimanfaatkan sensitivitasnya oleh sebagian kelompok untuk kepentingan pencitraan tanpa memperhatikan nilainilai luhur Pancasila. Pancasila rentan dijadikan sebagai komoditas politik, sehingga
\end{abstract}


menganggap bahwa golongan tertentu merasa Pancasilais dan kelompok lain tidak Pancasilais. Hasil penelitian ini memberikan petunjuk bahwa seharusnya semua kelompok dapat menempatkan Pancasila sebagai ideologi dalam berbangsa dan bernegara, dan menjadi evaluasi bersama dalam merevitalisasi nilai-nilai luhur yang terkandung dalam Pancasila sebagai aturan dasar, pedoman dan falsafah hidup bangsa Indonesia yang harus diamalkan sebagai perwujudan Bhineka Tunggal Ika.

Kata Kunci: Pancasila; politik; pencitraan.

\section{Pendahuluan}

Kemerdekaan Negara Republik Indonesia ditandai dengan dibacakannya naskah proklamasi oleh Soekarno-Hatta, dengan mengatasnamakan "Bangsa Indonesia." Ada banyak faktor pembentuk yang mengorbitkan sebuah bangsa yang bernama bangsa Indonesia tersebut. Jika menurut Renan hanya ada satu prinsip yang mendasari pembentukan suatu bangsa, yakni hasrat ingin bersatu, didalamnya terdapat banyak faktor yang menyertainya. Begitu pula dengan pembentukan bangsa Indonesia boleh dikatakan sebagai fakta yang unik, ditinjau secara historis Indonesia merupakan negara bekas jajahan (colonia) dari beberapa Negara, seperti Belanda dan Jepang. ${ }^{1}$ Negara ini tadinya merupakan sebuah wilayah kepulauan yang dikenal dengan sebutan Nusantara. Di dalamnya terdapat banyak kerajaan-kerajaan kaya yang berdaulat dan memiliki pemerintahan secara terpisah dan berdiri sendiri. Artinya, Negara Indonesia telah memiliki lebih dari cukup nilai kemandirian untuk mengelola pemerintahannya, sehingga lebih dari pantas untuk menyandang gelar sebagai Negara maju. ${ }^{2}$ Sederet sejarah tersebut menunjukkan bahwa Bangsa Indonesia ini terbentuk

1 Cahyo Budi Utomo Adhi Wahyu Nugraha, "Peristiwa 03 Oktober 1945 Di Kota Pekalongan (Analisis Dampak Sosial \& Dampak Politik)," Journal of Indonesian History 7, no. 1 (2018): hlm. 83.

2 Editor, "Jaya Maritimku Jayalah Indonesiaku," in Jaya Maritimku Jayalab Indonesiaku (Ditjen Pendidikan Anak Usia Dini dan Pendidikan Masyarakat - Kementerian Pendidikan dan Kebudayaan, 2018), h. 4-5. Pertama, kerajaan Sriwijaya dikenal dengan kerajan Budha terbesar yang berdiri pada abad ke VI masehi, wilayah kekuasaan kerajaan Sriwijaya ini sangat luas bahkan melintasi beberapa negara yang saat ini tergabung ke dalam ASEAN, yakni Kamboja, Thailand bagian selatan, Semenanjung Malaya. Sedangkan yang menjadi bagian wilayah Indonesia saat ini meliputi Sumatera, pesisir barat Kalimantan hingga Jawa bagian barat. Selanjutnya, yang menajadi pusat Kerajaan Sriwijaya terletak di antara Bukit Siguntang dengan Sobakingking (Palembang, Sumatra Selatan). Kedu , kerajaan Majapahit yakni kerajaan yang berdiri di wilayah Tarik Kabupaten Mojokerto Jawa Timur sekarang, kerajaan ini berkembang dari tahun 1293-1500, kerajaan Majapahit dikenal dengan kemampuannya melakukan penaklukan terhadap pasukan Kubilai Khan dibawah kepemimpinan Raden Wijaya, yang pada akhirnya dinobatkan menjadi Raja Majapahit dengan gelar Sri Jayawardhana berlangsung pada tahun 1293-1309. Ketiga, selain dua kerajaan besar di atas masih banyak kerajaan-kerajaan lain yang memiliki wilayah pemerintahan di nusantara ini, mulai dari kerajaan terbesar hingga kerajaan terkecil, seperti halnya kerajaan Kertanegara, kerajaan Tarumanagara serta beberapa kerajaan lainnya. 
atas dasar keinginan bersatu, hidup bersama, dan memiliki tujuan yang sama, salah satunya adalah mewujudkan kemerdekaan dan membebaskan diri dari cengkeraman penguasaan kolonialisme pada saat itu. Hasrat keinginan bersatu tersebut dibarengi dengan beberapa faktor pembentuk, seperti kesamaan nasib dan historis. Walaupun demikian, pada faktanya bangsa Indonesia dikenal sebagai bangsa yang memiliki tingkat keragaman tinggi, baik dari sisi ras, etnis maupun agama. Sekalipun demikian, tingkat heteregonitas yang tinggi tidak selalu menjadi kendala dalam melaksanakan upaya pencapaian tujuan bersama tersebut, hal ini dibuktikan dengan telah berdirinya Negara Republik Indonesia (NRI).

Bangsa Indonesia sebagai suatu bangsa yang unik, karena keanekaragaman yang dimilikinya, baik itu dari sisi etnis, ras maupun agama. Kehidupan berbangsa dan bernegara merupakan satu kesatuan yang pasti dialami dan dimiliki oleh seorang individu atau warga Negara. ${ }^{3}$ Boleh jadi sebab keanekaragaman yang dimiliki oleh bangsa kita menjadi salah satu faktor yang ikut menyumbang sedikit kerikil dalam perjalanan pendirian NRI ini, diantara peristiwa atau dinamika tersebut yang paling terkenal adalah pada proses penentuan dasar negara. Kemelut pro-kontra penentuan dan penetapan dasar negara ini sebenarnya telah dimulai sejak sidang BPUPKI pada tahun 1945, sidang konstituante 1955-1999, pada sidang istimewa MPR tahun 1998 diprakarsai oleh PPP yang mengajukan Piagam Jakarta dijadikan sebagai dasar negara, bahkan sampai pada tahun 2000 ketika Badan Pekerja MPR sedang melakukan amandemen UUD 1945 yang ke-2 kalinya, PPP bersama-sama dengan PBB mengajukan hal yang senada, agar ditetapkannya Piagam Jakarta sebagai dasar negara Indonesia. ${ }^{4}$ Primodialisme yang mendominasi pada fakta ini berasal dari aspek agama yang biasanya menjadi sasaran empuk, sebagaimana di ketahui beberapa tragedi yang terjadi di tanah air, misal kasus Poso, Konflik Suni dan Syi'ah di Jawa Timur, dan Konflik Agama di Bogor. ${ }^{5}$ Selain agama, ada beberapa model primodialisme lain yang menjadi batu sandungan dalam fakta dan peristiwa sejarah Negara Indonesia, seperti tragedi sampang salah satunya. ${ }^{6}$

Pada masa modern sekarang pun masih terdapat gejala kepentingan yang bersifat kelompok kecil masih berpotensi menjadi sebuah permasalahan dalam hal yang menyangkut kepentingan umum, yakni keberlangsungan hidup berbangsa dan bernegara. Padahal pada dasarnya setiap warga negara memiliki

3 Lutfi Fahrul Rizal, “(De) Sentralisme Kekuasaan: Kedudukan Pemimpin Terhadap Kasus,” Adliya : Jurnal Hukum Dan Kemanusiaan Volume 10 (2016). hlm. 35

4 Ulya, "Pancasila Simbol Harmonisasi Antar Umat Beragama Di Indonesia," Jurnal Ilmu Aqidab Dan Studi Keagamaan Volume 4 N (2016): hlm. 66.

5 Firdaus M Yunus, "Konflik Agama Di Indonesia Problem Dan Solusi Pemecahannya," Substantia 16, no. 2 (2014): 223-25.

6 J. Oliver, "Tragedi Salah Paham Antara Suku Lampung Dengan Suku Bali Di Lampung Selatan (Studi Kasus : Konflik Antar Suku)," Hilos Tensados 1, no. (2019): hlm. 96. 
hak dan kewajiban yang sama dalam melangsungkan kehidupan berbangsa dan bernegaranya. ${ }^{7}$ Akibat letupan-letupan tersebut maka terciptalah kelompokkelompok kecil yang bermunculan sebagai competitor atau bahkan bisa saja berperan sebagai provokator yang merasa paling benar dan menyalahkan kelompok lain. Selain itu, keadaan yang sedemikian rupa tanpa disadari akan sangat dengan mudah dimanfa'atkan oleh orang-orang yang memiliki kepentingan tanpa harus memperdulikan keadaan dan nasib bangsa Indonesia itu sendiri.

Sepanjang tahun 2014 hingga 2019, terutama pada saat momentum politik pemilihan umum Presiden dan Wakil Presiden tahun 2014 dan 2019, sangat rentan terjadi konflik kepentingan antar kelompok kecil yang seolah mengesampingkan kepentingan umum. Hal ini belum pernah terjadi pada perhelatan pemilu sebelumnya, jika pada pemilu sebelumnya gejolak dinamika perpolitikan hanya dirasakan pada tataran elit atau kalangan menengah ke atas saja, berbeda dengan dua pemilu belakangan ini yang mampu menyentuh akar rumput atau masyarakat bawah sekalipun. Penulis menilai sebuah isu politik yang diangkat ke permukaan adalah satu hal yang menjadi daya tarik masyarakat melek politik, secara khusus pada kedua pemilu terakhir. Adapun beberapa isu politik yang gencar dilakukan salah satunya adalah penyuaraan jargon "Saya Indonesia, Saya Pancasila". Pada mulanya jargon tersebut disuarakan bertepatan dengan Hari Lahir Pancasila tanggal 1 Juni 2017, yang dilakukan oleh salah satu kontestan pemilu presiden dan wakil presiden tahun 2019. Selanjutnya, jargon tersebut berlanjut dan digunakan oleh salah satu kontestan politik pada pemilihan Gubernur DKI Jakarta, yang diklaim sebagai pembeda antara kelompok pendukung Ahok (Basuki Tjahaja Purnama) dan yang non Ahok. Seterusnya peristiwa ini masih berlanjut, sehingga pada momentum perhelatan pemilu 2019 masih digunakan. Artinya, Pancasila sebagai dasar Negara yang memiliki sakralitas value, dapat dijadikan komoditas politik untuk mencapai kepentingan kelompok.

Tentunya, penggunaan kalimat/jargon seperti di atas, dinilai oleh Komnas HAM berbahaya. Menurut Hafid Abbas ${ }^{8}$ penggunaan kalimat tersebut seharusnya adalah dengan kalimat "Kita" bukan "Saya" sebab dengan menggunakan kalimat "Saya" hal ini akan berakibat pada pembenaran kelompok untuk menyalahkan atau bahkan menyerang kelompok lain, pada akhirnya akan berpotensi dalam membentuk kelompok-kelompok kecil di dalam bangsa ini.

Beberapa catatan penting mengenai penghayatan dan pengamalan nilainilai Pancasila dalam berbangsa dan bernegara. Sebagaimana yang diungkapkan oleh Indra Jaya dalam penelitianya yang berjudul Nalar Pancasila dalam

7 Lutfi Fahrul Rizal, “Analisis Prinsip Al-Hurriyah Terhadap Hak Politik Pegawai Negeri (Tni Dan Polri) Di Indonesia Ditinjau Dari Demokrasi Dan Ham," Adliya: Jurnal Hukum Dan Kemanusiaan Volume 9 N (2015): 288-316.

8 Bimo Wiwoho, “Jargon "Saya Indonesia, Saya Pancasila” Rawan Disalahgunakan," CNN Indonesia, 2021, https://www.cnnindonesia.com/nasional/20170609144023-20-220619/ jargon-saya-indonesia-saya-pancasila-rawan-disalahgunaka. 
Komunikasi Politik ${ }^{9}$, bahwa nalar Pancasila merupakan pengejawantahan nilainilai Pancasila sebagai landasan etik dalam melakukan komunikasi politik, sehingga komunikasi politik tidak lagi dijadikan hanya sebagai alat untuk meraih kepentingan politik, tetapi harus berkhidmat kepada kepentingan dan cita-cita bangsa dan negara sebagaimana tercantum dalam Pembukaan Undang-Undang Dasar 1945. Selain itu bukti peristiwa ketersinggungan atau sensitivitas yang terjadi pada bangsa kita belakangan ini adalah kasus rasisme yang dialami oleh Natalius Pigay, mantan komisioner Komnas HAM, disinyalir tidak hanya semata-mata rasisme, juga politis. Hal ini bermula ketika Pigay melakukan kritik terhadap rencana vaksinasi Covid-19 sinovac yang diwajibkan oleh pemerintah terhadap masyarakat Indonesia. Pigay merasa bahwa vaksinasi adalah hak bagi masyarakat untuk menerima atau menolak kebijakan vaksinasi tersebut tanpa harus dilakukan pemaksaan dengan dalih apapun. Akibat kritik yang disampaikannya, Pigay mengalami perundungan rasis yang dilakukan oleh orang-orang yang tidak bertanggungjawab dengan cara menyandingkan foto dirinya dengan seekor hewan gorila dengan caption bahwasannya vaksin hanya untuk manusia dan bukan untuk hewan tersebut. Sementara itu, masih ada kasus lain yang serupa, yaitu dugaan penistaan agama yang dilakukan oleh beberapa orang terhadap agama Islam dan Budha. ${ }^{10}$ Sementara dinyatakan Agus Syamsudi dalam artikelnya, yang secara tegas mengatakan bahwa bukan berarti yang dilakukan adalah penolakan terhadap Pancasila sebagai ideologi atau nilai dasar suatu negara. Namun, pengertian ideologi Pancasila yang selama ini telah kabur, seringkali digunakan untuk mengawetkan ambisi kekuasaan dalam wilayah otoritarianisme inilah yang tertolak. ${ }^{11}$

Berdasarkan fakta tersebut, penulis berasumsi bahwa peristiwa-peristiwa tersebut merugikan dan lambat laun akan mengancam keutuhan bangsa, dan tentu saja hal ini tidak boleh dibiarkan begitu saja. Selain itu, nilai-nilai luhur yang dimiliki oleh Pancasila sebagai ideologi bangsa masih belum teraktualisasi dengan baik dan benar.

Penelitian ini bertujuan untuk mengukur tingkat penghayatan dan pengamalan nilai-nilai Pancasila sebagai ideologi bangsa Indonesia secara utuh, sehingga nilai-nilai di dalamnya benar-benar dapat diterapkan dalam kehidupan berbangsa dan bernegara. Adapun peran dan fungsi ideologi Pancasila itu sendiri dan termasuk di dalamnya yang disebut dengan empat pilar kebangsaan, meliputi: Pancasila, UUD 1945, NRI dan Bhinneka Tunggal Ika, memiliki tujuan yang mulia secara umum, yakni mempertahankan keutuhan dalam ke-

9 Indra Jaya, "Nalar Pancasila Dalam Komunikasi Politik," Forum Ilmiah 14, no. Mei (2017): 188-97.

10 Irwan Ahmad Akbar, "Dinamika Kasus Penistaan Agama Di Indonesia (Polemik Pemaknaan Ayat-Ayat Penistaan Dan UU Penodaan Agama)," Qof 3, no. 1 (2019): 89-105, https://doi.org/10.30762/qof.v3i1.1068.

11 Akbar, hlm. 100. 
hidupan berbangsa dan bernegara sebagaimana yang menjadi harapan dan tumpuan cita-cita bangsa yang tercantum dari alinea ke-1 hingga ke-4 UUD $1945 .{ }^{12}$

\section{Metodologi}

Penelitian ini dilakukan dengan menggabungkan dua penelitian hukum, yaitu penelitian hukum normatif (doctrinal legal research) dengan penelitian hukum empiris (empirical legal research). Peneliti tidak hanya melihat hukum hanya dalam ruang lingkup disiplin saja, tetapi memandang hukum pada aspek normatif, seperti berkaitan dengan asas-asas hukum, sistematika hukum, sinkronisasi hukum, perbandingan hukum dan sejarah hukum. ${ }^{13}$ Selain itu, peneliti juga melihat pada aspek kenyataan perkembangan hukum di masayarakat (socio empirical legal research) yang bersifat deskriptif pada aspek implementasi atau operasionalisasinya. ${ }^{14} \mathrm{Hal}$ ini dimaksudkan untuk menilai dan menganalisis tingkat relevansi fakta dan cita-cita hukum di masyarakat, dalam hal ini adalah Pancasila sebagai aturan/hukum dasar Negara Indonesia.

\section{Hasil dan Pembahasan}

\section{Ideologi Pancasila dan Bangsa Indonesia}

Suatu hal yang dianggap sakral, dijunjung dan dihormati oleh orang banyak seyogyanya dapat digunakan untuk mencapai cita-cita atau kepentingan bersama pula. Bukan sebaliknya, malah dipergunakan untuk diambil manfaatnya demi kepentingan politik sekelompok orang. Terlebih lagi hal tersebut dapat memberikan dampak yang sangat fatal dan merugikan keutuhan bangsa dan negara. Ideologi merupakan kalimat familiar yang sering dijumpai dalam ruang dan waktu apapun. Kalimat "ideologi" mensiratkan padanya terdapat nilai-nilai dan kandungan yang sarat dengan sakralitas. Berkaitan dengan ideologi pula melekat nilai-nilai sensitivitas dan ketersinggungan yang berpotensi rawan terjadi. Sebab, setiap tindakan yang mengganggu atau mengusiknya dapat menimbulkan konsekwensi dan dampak yang sangat besar.

Secara bahasa, ideologi berasal dari dua kalimat, yakni "ideas" yang secara bebas diartikan sebagai gagasan, konsep, pengertian dasar, idea tau cita-cita. Sedangkan, kalimat yang kedua adalah "logos" yang diartikan sebagai ilmu. Jadi, ideologi tersebut dapat diasumsikan sebagai pengetahuan ide dasar (science of ideas) atau sebuah ajaran yang yang memuat tentang pengertian-pengertian hakikat dan atau dasar suatu hal.

12 Lutfi Fahrul Rizal, "Parliamentary Dan Presidential Threshold: Dalam Tokritik Politik Islam Kontemporer," ADLIY A: Jurnal Hukum Dan Kemanusiaan 11, no. 1 (2019): 137

13 Depri Liber Sonata, "Metode Penelitian Hukum Normatif Dan Empiris: Karakteristik Khas Dari Metode Meneliti Hukum," Fiat Justitia Jurnal Ilmu Hukum Volume 8 N (2014): 26.

14 Sonata, hlm. 27. 
Ideologi memiliki cakupan yang sangat luas, tergantung dari aspek mana sudut pandangnya, apakah dari aspek politik, pendidikan, budaya ataupun yang lainnya. Secara khusus maksud dalam penulisan ini yakni, ideologi yang terkait dengan aspek politik atau kenegaraan. Secara sederhana ideologi diartikan sebagai sumber nilai dalam kehidupan berbangsa dan bernegara yang pada tahapan selanjutnya dijabarkan dalam bentuk regulasi atau ketentuan peraturan perundang-undangan yang berlaku, selain itu ideologi pula dapat difungsikan sebagai bentuk kepribadian suatu bangsa, sebab didalamnya melekat nilai-nilai luhur yang menjadi ukuran dan tolak ukur dalam kehidupan berbangsa dan bernegara. ${ }^{15}$

Kepentingan sebuah ideologi pada suatu negara memiliki kendali yang sangat sentral dan sangat menentukan arah kehidupan berbangsa dan bernegara itu sendiri. Artinya, eksistensi sebuah ideologi sangat berpengaruh terhadap kelangsungan dalam penyelenggaraan negara. Sebab dalam ideologi telah termuat nilai-nilai dasar yang menjadi acuan dan pedoman yang harus dijunjung tinggi serta diikuti oleh siapapun yang terangkum dalam kehidupan berbangsa di suatu negara. Misal, Lenin pernah menjunjung tinggi nilai komunisme dalam penyelenggaraan pemerintahannya, begitupun dengan Indonesia melalui ideologi Pancasilanya.

Keberadaan Pancasila sebagai ideologi negara, daripadanya masih terdapat dua pendapat yang bersebrangan, antara mereka yang menyebutnya sebagai ideologi dan yang tidak. Katakanlah pendapat yang dikemukakan oleh Onghokham, menyebut bahwa Pancasila merupakan sebuah dokumen politik dan bukan ideologi ataupun falsafah yang harus dilihat sebagai bentuk kesepakatan diantara warga-warga negara yang selanjutnya disebut dengan kontrak sosial, hal ini tidaklah jauh berbeda dengan dokumen "Bill of Rights" di Amerika Serikat, Magna Charta di Inggris, dan Droit de l'home di Prancis. ${ }^{16}$ Disamping itu, para pihak yang masih mempertahankan argumentasinya akan keberadaan Pancasila sebagai ideologi dipelopori oleh para ahli seperti Kuntowijoyo, Azyumardi Azra, Asvi Warman Adam dan Budiarto Danujaya serta beberapa tokoh lainnya. ${ }^{17}$

Terlepas dari perbedaan sudut pandang yang terjadi terkait Pancasila sebagai ideologi, penulis berpandangan secara historis bahwa penyusunan dan perumusan Pancasila itu sendiri telah menghabiskan waktu yang tidak singkat, dan melalui banyak perhelatan dinamika serius di dalamnya. Misal, perdebatan yang terjadi pada saat penetapan dasar negara membuat majelis sidang terbagi kepada 2 (dua), antara lain Kubu Pancasila dan Kubu Piagam Jakarta, kemudian disitu terjadi perdebatan dan upaya konsensus yang sangat alot. Atas hal ini

15 Reno Wikandaru, "Landasan Ontologis Sosialisme," Jurnal Filsafat Volume 26 (2016): hlm. 113.

16 Agus Wahyudi, "Ideologi Pancasila: Doktrin Yang Komprehensif Atau Konsepsi Politis?" Volume 39 (2006): hlm. 95.

17 Wahyudi. 
penulis anggap sebagai indikator kehati-hatian dan keseriusan para founding father dalam merumuskan dasar negara, sebab inilah yang diyakini akan memberikan pengaruh besar dalam penyelenggaraan kehidupan berbangsa dan bernegara pada nantinya. Oleh karenanya, penulis sepakat dengan ungkapan yang dinyatakan Agus Syamsudi dalam artikelnyanya, yang secara tegas mengatakan bahwasanya bukan berarti yang dilakukan adalah penolakan terhadap Pancasila sebagai ideologi atau nilai dasar suatu negara. Namun, pengertian ideologi Pancasila yang selama ini telah kabur, seringkali digunakan untuk mengawetkan ambisi kekuasaan dalam wilayah otoritarianisme inilah yang tertolak. ${ }^{18}$

Banyak para ahli yang mengartikan sebuh bangsa (nation) sesuai dengan kapasitas dan cara pandangnya. Bangsa merupakan kumpulan dari beberapa komponen masyarakat yang disatukan oleh beberapa sebab dan rasa. Dalam pengertiannya yang lebih detail, bangsa (nation) diartikan sebagai suatu kumpulan orang yang memiliki asal dan kesamaan keturunan, adat, bahasa, sejarah dan pemerintahannya tersendiri yang berdaulat. Setidaknya, ada beberapa unsur penting yang harus dimiliki sekelompok manusia tersebut agar dapat diartikan sebagai sebuah bangsa, beberapa unsur konstitutif bangsa tersebut diantaranya:

Sekumpulan manusia, bangsa merupakan entitas yang terdiri dari banyak orang atau masyarakat yang berkumpul dalam satu wilayah dan kesatuan yang sama serta memiliki batasan-batasan dalam teritorialnya sehingga menjadi tanda atau ciri antara bangsa yang satu dengan yang lainnya;

Kesamaan keturunan, ikatan keturunan pun berperan penting dalam membentuk rasa (feel) antara manusia dengan manusia yang lainnya, sehingga akan dengan mudah tercipta chemistry diantara kumpulan manusia tersebut. Rasa kesamaan chemistry inilah yang nantinya mampu menjadi pengikat dalam satu kesatuan sebuah bangsa. Kesamaan keturunan tidak selalu diartikan sebagai sebuah keluarga dalam arti yang sempit dan terbatas, akan tetapi lebih dari itu keturunan disini diartikan lebih luas yang merujuk kepada asal muasal kelahiran manusia itu sendiri, bisa jadi diangkat dari kesejarahan nenek moyang atau leluhurnya;

Kesamaan adat, antar setiap manusia dipastikan memiliki keunikan dan perbedaan masing-masing yang dimilikinya, adapun ukuran besar can kecil perbedaan tersebut sangatlah relatif. Perbedaan sesama manusai pasti ada, sekalipun manusia itu sendiri memiliki gen kelahiran kembar identik. Memang secra fisik boleh saja memiliki kesamaan, akan tetapi ada perbedaan lain yang bisa dilihat dari aspek lainnya, seperti sikap, perilaku atau kebiasaan lain diantara kedua atau lebih manusia kembaran itu. Adat diartikan sebagai sebuah kebiasaan yang dilakukan secara berulang-ulang dan bersifat berkelanjutan (continuitas), sebuah tindakan yang dikaitkan dengan adat, setidaknya didasari oleh tiga unsur penting, yakni : pertama, pandai, artinya sikap atau perilaku tersebut dilakukan atas dasar keahlian yang dimiliki oleh orang, sebab tanpa keahlian atau keinginan

18 Wahyudi, hlm. 100. 
untuk belajar dalam melakukan suatu perilaku tersebut akan sangat tidak mungkin bisa mencapai tingkat kepandaian, sehingga unsur kepandaian inilah yang menjadi kunci perbuatan/perilaku dilakukan secara berkala (continuitas), kedua, manfaat, kegiatan atau tindakan yang dilakukan benar-benar memberikan manfaat dan nilai kegunaan yang sangat berarti bagi kelompok atau individu manusia itu sendiri, manfaat atau keguanaan tersebut sangat luas jenisnya, baik itu secara ekonomis, politis ataupun yang lainnya; dan ketiga, hobi, sebuah perbuatan atau tindakan yang dilakukan dapat membentuk rasa suka atau senang bagi yang melakukannya, sehingga dengan begitu akan melahirkan nilai kerelaan atau keikhlasan dalam setiap tindakan atau perbuatan tersebut dilakukan secara terus menerus;

Kesamaan sejarah, sebagai manusia yang memiliki kehidupan secara bersama-sama dalam suatu wilayah dan waktu yang lama, bangsa tentunya diwujudkan juga oleh rasa persamaan nasib, sepenanggungan dan sejarah yang telah lama dilalui olehnya secara langsung maupun yang tidak langsung, seperti keadaan sejarah yang hanya dialami oleh orang tua, kakek-nenek atau keturunan lainnya yang telah ada lahir dan meninggal mendahului mereka. Sekalipun demikian, rasa yang pernah dirasakan oleh keturunan mereka dahulu relatif sangat kental dan dirasakan pula oleh manusia generasi penerusnya, rasa ini akan terus terbawa dan diwariskan secara terus meneurus kepada keturunan mereka yang akan datang setelahnya, contohnya seseorang yang berasal dari keturunan veteran/pejuang kemerdekaan yang meninggal di tangan kolonial biasanya memiliki rasa benci yang tinggi terhadap negara kolonial tersebut, dan bahkan bisa lebih menunjukkan rasa nasionalisme yang lebih tinggi pula jika dibandingkan dengan yang lainnya; dan

Pemerintahan yang sah, bangsa berada dibawah keandali suatu pemerintahan yang sah dan diakui. Pemerintah memiliki peran dan fungsi yang sangat sentral dalam mengatur serta menjaga keutuhan suatu bangsa. Terlebih, jika dalam suatu bangsa tersebut memiliki tingkat kerawanan dan sensitivitas yang tinggi, baik itu pada aspek agama, politik, ras ataupun yang lainnya.

Secara sederhana, Ernest Renan mengartikan bangsa sebagai suatu kelompok manusia yang sama-sama memiliki hasrat untuk bersatu padu dan membentuk sebuah kesatuan (le desire de vivre ensemble). ${ }^{19}$ Dalam hal ini, Renan berpandangan bahwa keberadaan suatu bangsa tidak ditentukan oleh beberapa faktor sebagaimana yang telah disebutkan, baik itu agama, ras, adat ataupun etnis. Sebab, menurutnya ketika hal tersebut dijadikan landasan dalam pembentukan suatu bangsa maka akan menjadi bom waktu bagi keutuhan bangsa itu sendiri. Pencampuradukan unsur-unsur primodialisme selain rasa ingin bersatu dan hidup bersama, seperti ras, bahasa, agama, persekutuan kepentingan, keadaan alam geografi ke dalam suatu bangsa akan memperkeruh nilai

19 Muhammad Mustaqim dan Muhamad Miftah, "Tantangan Negara-Bangsa (Nation-State) Dalam Menghadapi Fundamentalisme Islam,” Jurnal Addin Volume 9 N, no. h. 87 (2015). 
persatuan yang terdapat dalam bangsa, sebab semakin banyak primodialisme, maka akan semakin banyak pula nilai-nilai sensitif dan ketersinggungan yang akan terjadi dalam bangsa tersebut, akibatnya tidak ada jaminan suatu bangsa akan terus utuh. Menurutnya, jika saja unsur-unsur konstitutif bangsa yang telah disebutkan dapat membentuk kolektifitas suatu bangsa, tetapi hanya akan mendapatkan hampa nilai dari kehendak bersatu atau hidup bersama, akibatnya lambat laun akan melahirkan rasa lain seperti keterpaksaan, minoritas dan mayoritas, gerbong atau golongan dan yang lainnya. ${ }^{20}$

Bangsa Indonesia kini telah memiliki usia senja ke-75, sebuah pencapaian yang sangat baik dalam merawat keragaman serta kerukunan kehidupan berbangsa dan bernegara. Bangsa Indonesia merupakan bangsa yang memiliki kurang lebih 300 kelompok etnik atau suku bangsa, lebih tepatnya terdapat 1.340 suku bangsa yang ada di Tanah Air berdasarkan sensus yang dilakukan Badan Pusat Statisti (BPS) tahun 2010, dengan dominasi suku Jawa yang paling besar jika dibandingkan dengan suku bangsa yang lainnya. ${ }^{21}$

\section{Fenomenal Pancasila dalam Politik Pencitraan}

Sejarah perkembangan ideologi Pancasila telah berlangsung selama kurang lebih 75 tahun, dimulai sejak negara ini diproklamirkan. Pancasila memiliki momentum politis tersendiri dalam setiap perkembangan pemerintahan di negara ini, hal inilah yang kemudian memunculkan asumsi penafsiran daripada pengertian ideologi Pancasila yang keberadaannya untuk melanggengkan ambisi kekuasaan (totalitarianism), beberapa peistiwa tersebut diantaranya:

Pertama, pada masa perumusan Pancasila sebagai dasar Negara dan UndangUndang Dasar 1945 di masa pemerintahan orde lama, telah menuai perdebatan panjang dan berakhir dengan sikap legowo yang dilakukan oleh perwakilan dari umat Islam. Polemik ini dimulai pada saat sidang BPUPKI tahun 1945 dan seterusnya. Beberapa kali musyawarah yang membahas dasar Negara dilakukan, dalam keputusannya cenderung terkesan politis, hingga pada akhimya diperkuat dengan pembubaran partai politik Masyumi yang dianggap sebagai partainya umat Islam. Padahal kondisi masyarakat Indonesia pada saat itu secara mayoritas, yakni sebanyak 90-95\% merupakan muslim. ${ }^{22}$ Artinya, sebuah logika yang sangat masuk akal mengingat kontribusi umat Islam yang begitu besar dalam upaya mewujudkan kemerdekaan Negara Republik Indonesia. Oleh karenanya, sudah menjadi hak

20 Ibid, hlm.89 atau lihat pula Ernest Renan, Apakah Bangsa Itu?, (Jakarta: Alumni, 1994).

21 Editor, "Suku Bangsa" dalam https://indonesia.go.id/profil/suku-bangsa/kebudayaansukubangsa\#: :text=Indonesia $\% 20$ memiliki $\% 20$ lebih $\% 20$ dari $\% 20300$,menurut $\% 20$ sensus $\% 20$ BPS $\% 20$ tahun $\% 202010$, diakses pada 28 April 2021

22 Mujar Ibnu Syarif, "Spirit Piagam Jakarta Dalam Undang-Undang Dasar 1945," Jurnal Cita Hukum Volume 4 N (2016): hlm. 22. atau lihat juga Endang Saifuddin Anshari, Piagam Jakarta 22 Juni 1945 Sebuab Konsensus Nasional Tentang Dasar Negara Republik Indonesia (19451959) (Gema Insani Press, 1997). 
bangsa Indonesia untuk menentukan arah dan kebijakan penyelenggaraan Negara ke depan, salah satunya dalam perumusan dasar Negara tersebut. Beberapa peristiwa politis lain yang terjadi pada masa ini, yakni dilakukannya pembentukan Nasakom (Nasionalis Agama dan Komunis) oleh Soekarno pada saat itu. Tujuan dari pembentukan NASAKOM diamksudkan untuk mengakomodir berbagai ideologi yang berkembang di Indonesia ke dalam satu wadah, demi mewujudkan kepentingan politik semata.

Kedua, pemberlakuan Undang-Undang Nomor 3 Tahun 1985 yang disahkan pada 19 Februari 1985 atau yang lebih dikenal dengan sebutan "UU asas tunggal" merupakan suatu bentuk kediktatoran yang dilakukan oleh pemerintah pada saat itu, sebab dinilai telah memaksakan kehendak kepada setiap organisasi agar menggunakan Pancasila sebagai asas tunggal dalam AD/ART organisasi atau dinyatakan bubar. Telah disepakati bahwasanya keberadaan Pancasila merupakan suatu bentuk akomodatif terhadap piagam Jakarta dan beberapa consensus yang telah dimusyawarahkan dalam perumusannya kala itu, artinya suatu hal yang tidak diperlukan dilakukan undang-undang tersebut diundangkan, selama asas-asas yang telah dipakai oleh setiap organisasi tersebut tidak bertentangan dengan Pancasila.

Ketiga, pada pelaksanaan pemilihan umum tahun 2019 telah terjadi peristiwa yang tidak biasanya. Manakala pada saat itu, massa pemilih seolah-olah terbagi kepada dua bagian atau kubu, mengingat pasangan calon presiden dan wakil presiden yang masuk dalam bursa pencalonan sebanyak dua pasangan, yakni pasangan calon nomor urut 01 Joko Widodo dan Ma'ruf Amin, sedangkan yakni pasangan calon nomor urut 02 Prabowo Subianto dan Sandiaga Uno. Menjelang perhelatan kontestasi demokrasi tersebut, berseliweran isu politik yang dianggap kurang baik, sebab hal ini mempertaruhkan nilai keutuhan bangsa itu sendiri. Pada saat itu muncul jargon yang menyuarakan "Saya Pancasila, Saya Indonesia" yang kemudian disemarakkan oleh pendukung salah satu pasangan calon yang seolah-olah secara tidak langsung memberikan sinyal klaimisasi salah satu kelompok saja yang benar, hanya yang menjadi bagian dari merekalah yang mengakui Pancasila sebagai Ideologi, serta menyalahkan massa atau kubu yang lain. Hal ini tentu saja sangat berbahaya dan mengancam persatuan dan kesatuan, ketika satu golongan menganggap dirinya paling benar dan menyalahkan golongan atau kelompok yang lain, terlebih dinamika tersebut tidak hanya terjadi pada masa politik saja melainkan berlanjut ke dalam wilayah sosial, hal ini terlihat dari obrolan di warung kopi ataupun perdebatan dan tweet yang berseliweran di sosial media.

Padahal, aktivitas politik beserta aktor-aktor didalamnya dianggap sebagai yang paling bertanggungjawab dalam mengawal dan mempertahankan nilai-nilai Pancasila demi terjaminnya kelangsungan hidup berbangsa dan bernegara dengan benar-benar menjadikan Pancasila sebagai falsafah hidup bangsa, bukan 
malah sebaliknya diawali dengan cara-cara yang bernuansa hanya sebatas "pencitraan" demi sebuah tujuan kepentingan kelompok terstentu.

Kegaduhan telah terjadi dalam waktu dekat di beberapa minggu terakhir ini, hal ini ditenggarai oleh adanya penerbitkan Peraturan Pemerintah Nomor 57 Tahun 2021 tentang Standar Nasional Pendidikan yang diteken oleh Presiden Joko Widodo pertanggal 30 Maret 2021, hal yang dipermasalahkan adalah sebab hilangnya Pancasila dan Bahasa Indonesia yang tidak disebutkan secara eksplisit sebagai kurikulum wajib dalam PP tersebut, beberapa pihak menfsirkan hal ini seolah bertentangan dan tidak sejalan dengan Undang Undang Nomor 12 Tahun 2012 Tentang Pendidikan Tinggi terutama pada pasal 35 Ayat 3 yang menyebut secara tegas keberadaan Pancasila dan Bahasa Indonesia sebagai mata kuliah yang termasuk ke dalam kurikulum wajib.

Padahal, jika dilakukan perbandingan dengan Undang-undang yang memiliki keterkaitan, seperti Undang-Undang Nomor 20 Tahun 2003 tentang Sistem pendidikan Nasional, terutama pada Pasal 4 dan Pasal 36-37 disana ditegasakan pula bahwa dalam kurikulum baik itu untuk pendidikan dasar maupun perguruan tinggi tidak ditegaskan sama sekali mengenai Bahasa Indonesia dan Pancasila, sebagaimana yang telah disebutkan secara eksplisit oleh Undang Undang Nomor 12 tahun 2012 tentang Pendidikan Tinggi. Dinamika ini tentu saja mengundang pro dan kontra serta membuat heboh seisi Indonesia dengan berbagai asumsi dan argumentasinya masing-masing.

Keadaan tersebut memaksa mendikbud Nadiem Makariem melayangkan surat Nomor 25059/MpK.A/HK.01.01/2021 perihal Ijin Prakarsa Penyusunan Peraturan Pemerintah tentang Perubahan Atas Peraturan Pemerintah Nomor 57 Tahun 2021 tentang Standar Nasional Pendidikan, dengan pertimbangan dua poin, yakni: pertama, dalam rangka pengamalan nilai-nilai Pancasila dalam kehidupan berbangsa dan bernegara yang perlu diintegrasikan ke dalam kurikulum pendidikan, serta; kedua, perlu dilakukan harmonisasi terhadap peraturan yang lebih tinggi.

Politik hukum dalam penyusunan peraturan perundang-undangan sudah seharusnya memberikan stimulus penguatan keberadaan Pancasila sebagai dasar Negara, ketimbang memperdebatkan suatu hal dengan tujuan unjuk gigi merasa paling "Pancasilais". Ada banyak cara yang bisa dilakukan didalam penguatan tersebut, contoh menyelenggarakan kegiatan seperti Pedoman Pengamalan dan Penghayatan Pancasila (P4) atau dalam bentuk lain namun memiliki subtansi tujuan yang sama. Jauh sebelum perumusan dilakukan oleh para pendiri bangsa Indonesia, setidaknya ada satu nilai universal yang dikehendaki oleh mereka walaupun pada kenyataannya memiliki persepsi yang berbeda terkait implementasi nilai tersebut. Nilai universal yang dimaksud adalah mempertahankan dan meningkatkan kesejahteraan NRI yang berdasarkan kepada nilai-nilai yang dianut. Oleh karenanya, menjadikan Pancasila sebagai objek yang tidak seharusnya, atau alat kepentingan kelompok adalah sebuah tindakan kejahatan, sebab telah menyalahi amanat/citacita luhur bangsa dan tentu saja mengancam nilai keutuhan dan kelangsungan hidup berbangsa dan bernegara. Maka dari itu perlu bagi kita untuk mengembalikan kemurnian dari nilai-nilai yang terkandung dalam Pancasila. 


\section{Kesimpulan}

Indonesia sebagai negara yang majemuk tentunya memiliki kelebihan dan kekurangan dalam penghayatan dan pengamalan Pancasila sebagai pedoman berbangsa dan bernegara. Sehingga menjadi sebuah keharusan setiap individu dan kelompok atau golongan untuk secara bersama-sama merawat kemajemukan itu dengan sebaik-baiknya. Karena itu, baik Pemerintah maupun rakyat harus mampu menjaga, merawat dan menyeimbangkan nilai-nilai tersebut untuk keutuhan bangsa dan negara. Beberapa peristiwa fenomenal yang erat hubungannya dengan Pancasila, memberi gambaran bahwa nilai-nilai luhur yang sejatinya dihormati dan dijunjung tinggi masih rentan dimanfaatkan sensitivitasnya oleh sebagian kelompok untuk kepentingan pencitraan tanpa memperhatikan nilai-nilai luhur Pancasila. Selain itu Pancasila rentan dijadikan sebagai komoditas politik, sehingga menganggap bahwa golongan tertentu merasa Pancasilais dan kelompok lain tidak Pancasilais. Pancasila sebagai ideologi dalam berbangsa dan bernegara menjadi sebuah evaluasi bersama dalam merevitalisasi nilai-nilai luhur yang terkandung dalam Pancasila sebagai perwujudan Bhineka Tunggal Ika.

\section{Daftar Pustaka}

Adhi Wahyu Nugraha, Cahyo Budi Utomo. "Peristiwa 03 Oktober 1945 Di Kota Pekalongan (Analisis Dampak Sosial \& Dampak Politik)." Journal of Indonesian History 7, no. 1 (2018): 83.

Akbar, Irwan Ahmad. "Dinamika Kasus Penistaan Agama Di Indonesia (Polemik Pemaknaan Ayat-Ayat Penistaan Dan UU Penodaan Agama)." Qof 3, no. 1 (2019): 89-105. https://doi.org/10.30762/qof.v3i1.1068.

Anshari, Endang Saifuddin. Piagam Jakarta 22 Juni 1945 Sebuab Konsensus Nasional Tentang Dasar Negara Republik. Indonesia (1945-1959). Gema Insani Press, 1997.

Editor. “Jaya Maritimku Jayalah Indonesiaku." In Jaya Maritimku Jayalah Indonesiaku, h. 4-5. Ditjen Pendidikan Anak Usia Dini dan Pendidikan Masyarakat - Kementerian Pendidikan dan Kebudayaan, 2018.

Jaya, Indra. "Nalar Pancasila Dalam Komunikasi Politik." Forum Ilmiah 14, no. Mei (2017): 188-97.

Miftah, Muhammad Mustaqim dan Muhamad. "Tantangan Negara-Bangsa (Nation-State) Dalam Menghadapi Fundamentalisme Islam.” Jurnal Addin Volume 9 N, no. h. 87 (2015).

Oliver, J. "Tragedi Salah Paham Antara Suku Lampung Dengan Suku Bali Di Lampung Selatan (Studi Kasus : Konflik Antar Suku)." Hilos Tensados 1, no. (2019): 96.

Renan, Ernest. Apakah Bangsa Itu?,. Jakarta: Alumni, 1994. 
Reno Wikandaru. "Landasan Ontologis Sosialisme." Jurnal Filsafat Volume 26 (2016): hlm. 113.

Rizal, Lutfi Fahrul. "(De) Sentralisme Kekuasaan: Kedudukan Pemimpin Terhadap Kasus." ADLIYA: Jurnal Hukum Dan Kemanusiaan Volume 10 (2016).

. "Analisis Prinsip Al-Hurriyah Terhadap Hak Politik Pegawai Negeri (TNI Dan POLRI) Di Indonesia Ditinjau Dari Demokrasi Dan Ham." ADLIY A: Jurnal Hukum Dan Kemanusiaan Volume 9 N (2015): 288-316.

_. "Parliamentary Dan Presidential Threshold: Dalam Tokritik Politik Islam Kontemporer." ADLIYA: Jurnal Hukum Dan Kemanusiaan 11, no. 1 (2019): 137-50. https://doi.org/10.15575/adliya.v11i1.4856.

Sonata, Depri Liber. "Metode Penelitian Hukum Normatif Dan Empiris: Karakteristik Khas Dari Metode Meneliti Hukum.” Fiat Justitia Jurnal Ilmu Hukum Volume 8 N (2014): 26.

Syarif, Mujar Ibnu. "Spirit Piagam Jakarta Dalam Undang-Undang Dasar 1945." Jurnal Cita Hukum Volume 4 N (2016): h. 22.

Ulya. "Pancasila Simbol Harmonisasi Antar Umat Beragama Di Indonesia." Jurnal Ilmu Aqidab Dan Studi Keagamaan Volume 4 N (2016): h. 66.

Wahyudi, Agus. "Ideologi Pancasila: Doktrin Yang Komprehensif Atau Konsepsi Politis?” Volume 39 (2006): h. 95.

Wiwoho, Bimo. "Jargon "Saya Indonesia, Saya Pancasila" Rawan Disalahgunakan.” CNN Indonesia, 2021. https://www.cnnindonesia.com/ nasional/20170609144023-20-220619/jargon-saya-indonesia-sayapancasila-rawan-disalahgunakan.

Yunus, Firdaus M. "Konflik Agama Di Indonesia Problem Dan Solusi Pemecahannya." Substantia 16, no. 2 (2014): 223-25. terms and conditions of the Creative Commons Attribution Share Alike (CC BY SA) license (https://creativecommons.org/licenses/by-sa/4.0/). 